\title{
Inhibition of NF-kB by Pyrrolidine Dithiocarbamate Prevents the Inflammatory Response in a Ligature- Induced Peri-Implantitis Model: A Canine Study
}

\author{
Chun-Yan He $^{\mathrm{a}}$ Li-Peng Jiang ${ }^{\mathrm{b}} \quad$ Cheng-Yue Wang ${ }^{\mathrm{c}} \quad$ Yue Zhang $^{\mathrm{a}}$ \\ ajinzhou Medical University, Jinzhou, bDepartment of Radiology, the First Affiliated Hospital of Jinzhou \\ Medical University, Jinzhou, 'Department of Stomatology, the Second Affiliated Hospital of Jinzhou \\ Medical University, Jinzhou, China
}

\section{Key Words}

Pyrrolidine dithiocarbamate $\cdot$ TLR4 $・ \mathrm{NF}-\mathrm{kB} \cdot$ Peri-implantitis $・$ Inflammation

\begin{abstract}
Background/Aims: The roles of toll-like receptor 4 (TLR4) and nuclear factor-kappa B (NF-kB) in peri-implantitis are unclear. Here, we used a canine model of peri-implantitis to explore the effects of inhibiting NF-KB with pyrrolidine dithiocarbamate (PDTC) on the inflammatory response in ligature-induced peri-implantitis. Methods: After successfully establishing the peri-implantitis model, beagles were randomly assigned to normal, model or PDTC groups. ELISA tests were used to determine the levels of interleukin (IL)-1, IL-6, IL-8 and tumor necrosis factor alpha (TNF- $\alpha$ ). Immunohistochemistry was employed to assess the expression of NF- $\mathrm{KB}$ p65. Reverse transcription-quantitative polymerase chain reaction (RT-qPCR) was performed to determine the mRNA levels of TLR4 and NF-KB p65, and western blot analysis was used to measure the protein levels of TLR4 in periodontal tissues from each group. Periodontal ligament fibroblasts (PDLFs) were cultured and subsequently classified into PDLF normal, PDLF model, PDLF LPS, PDLF PDTC, and PDLF LPS + PDTC groups. An immunofluorescence assay was used to measure the expression level of NF-KB p65. The CCK-8 assay and flow cytometry were performed to evaluate cell proliferation and apoptosis. Results: The in vitro results indicated that NF-KB p65 and TLR4 were upregulated in canine periodontal tissues, and PDTC could suppress the expression levels of NF-KB p65 and TLR4. Inflammation could increase TLR4 protein expression in canine periodontal tissue, and PDTC could inhibit the inflammation-induced increase in TLR4 protein expression. These results revealed that PDTC could reverse the LPS-induced increases in the levels of IL-1, IL-6, IL-8 and TNF- $\alpha$. In vivo, the results demonstrated that PDTC inhibited the LPS-induced NF-KB p65 upregulation, and PDTC




\section{Cellular Physiology Cell Physiol Biochem 2018;49:610-625

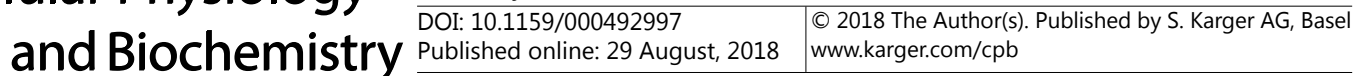 \\ He et al.: PDTC Inhibits NF-KB in Peri-Implantitis}

could reverse the inhibitory effect of the PDLF model + LPS on the proliferation of periodontal fibroblasts. The results also showed that in the PDLF model, LPS promoted PDLF apoptosis by inducing implant periodontitis in canines, but PDTC inhibited the PDLF apoptosis and relieved implant periodontitis in canines. Conclusion: Based on our results, we concluded that PDTC can inhibit the expression of NF-KB and alleviate the inflammatory response induced by LPS, thereby preventing periodontal inflammation and reducing the development of periimplantitis.

\section{Introduction}

Peri-implant diseases feature inflammatory lesions that may not only influence the periimplant mucosa but may even lead to the loss of supporting bone, namely, peri-implantitis, which in turn can result in implant loss [1]. Peri-implantitis is characterized by inflammation around the implant. This condition includes soft tissue inflammation and a decrease in the mass of supportive bone beyond routine biological bone remodeling [2]. This process has become an increasingly serious problem due to the growing number of patients receiving oral implants, and both the ability to predict susceptibility and pharmacological agents to reduce inflammation are of great clinical interest [3]. Clearly, healthy soft and hard periimplant tissues are needed for the survival and stability of dental implants [4]. The purpose of treatment in peri-implantitis is to decrease the bacterial load in the peri-implant pocket and decontaminate the implant surface to promote osseointegration [5]. Both surgical and non-surgical tools have been used to treat peri-implantitis, and there are various implant surface decontamination solutions, but consensus is still lacking regarding the most effective treatment in peri-implantitis [6]. However, the understanding of the pathogenesis of periimplantitis is incomplete and fragmented, and hence, the availability of an animal model to investigate inflammatory diseases might facilitate our understanding of the pathogenic mechanisms [7].

Toll-like receptors (TLRs) are the main receptors that modulate inflammatory and innate immune responses; among these, TLR4 is closely correlated with human atherosclerosis [8]. The pattern recognition receptor TLR4 is well known to be a vital receptor in inflammation and infection [9]. In addition, the nuclear factor-kappa B (NF- $\kappa \mathrm{B}$ ) transcription factors play a crucial role in regulating immune and inflammatory responses, cell proliferation and apoptosis [10]. Lipopolysaccharide (LPS) is the main pathogen-associated molecular pattern in the cell wall of gram-negative bacteria. In mammals, this pattern is recognized by TLR4 in combination with the serum protein, LPS-binding protein [11]. A previous study explored the role of TLR4 during LPS challenge in vivo. This challenge caused a dose- and time-dependent activation of NF- $\mathrm{KB}$ transcription in the caput and cauda epididymides [12]. Pyrrolidine dithiocarbamate (PDTC), a selective antioxidant and inhibitor of NF- $\kappa \mathrm{B}$, exerts anticonvulsant activity and has an important neuroprotective influence in the hippocampal CA1 and CA3 regions, potentially by attenuating microglial activation [13]. Additionally, PDTC has effective anti-inflammatory and anti-tumor properties [14]. Previously, several studies have shown that PDTC can affect inflammation, such as by inhibiting ultraviolet B-induced skin inflammation and by preventing neuroinflammation and cognitive dysfunction after endotoxemia $[15,16]$. However, few studies have clarified the relationships among PDTC, TLR4, NF- $\kappa B$ and peri-implantitis. Thus, the aim of this study was to investigate the effect of PDTC on NF- $\kappa B$ expression in a canine model of peri-implantitis. 


\section{Cellular Physiology Cell Physiol Biochem 2018;49:610-625

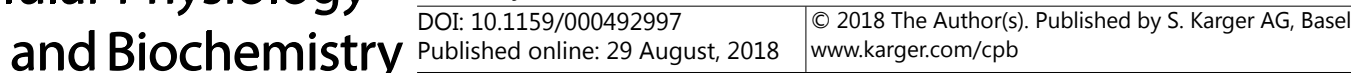 \\ He et al.: PDTC Inhibits NF-kB in Peri-Implantitis}

\section{Materials and Methods}

\section{Ethics statement}

This study was approved by the Ethics Committee of the Second Affiliated Hospital of Jinzhou Medical University.

Establishment of a canine model of peri-implantitis [17]

A total of 18 male beagle canines (10-20 months) (Guangzhou Pharmaceutical Industry Research Institute, Guangdong, China) were purchased at a weight ranging from 10.1-16.1 kg. Their mandibular premolars and first molars were extracted under general anesthesia. The mucoperiosteal flap was opened, three implants were placed on each side of the mandible and sutured tightly, and the wounds were allowed to heal for three months. The canines were intravenously injected with antibiotics after the operation and fed a soft diet. The sutures were removed after 10 days, and oral cleaning was conducted. The gum bases were opened again after healing for 3 - 5 months, and oral cleaning was again conducted. The sutures were removed under transient anesthesia after 2 weeks, and then the animals were assigned to the pyrrolidine dithiocarbamate (PDTC) (treated with an intraperitoneal injection of $1000 \mu \mathrm{mol} / \mathrm{mL}$ PDTC), model (treated with an intraperitoneal injection of normal saline), and normal (normal canines) groups, each consisting of 6 canines. The canines in the normal group were subjected to continuous oral cavity cleaning, whereas in the other two groups, blotted silk sutures were used in the implant necks, and oral cleaning was stopped. The canines were fed a soft diet to allow plaque and calculus accumulation and establish the canine model of peri-implantitis. Moreover, the canines were intraperitoneally injected with PDTC liquid (1000 $\mu \mathrm{mol} /$ $\mathrm{mL}$ ) (Sigma-Aldrich Corporation, St. Louis, MO, USA) or normal saline (one time per day). The soft tissue of the peri-implant was examined in the PDTC and model groups after 2 months. In most implants, gingival swelling was observed with a large quantity of overlaid plaque, part of which appeared to exhibit pyorrhea after probing, which suggested that the model was successfully established. The canines in the three groups were sacrificed, and the periodontal tissue was extracted to examine the gross morphology. The following analyses were performed on the most obviously pathological areas of the periodontal tissue.

\section{Hematoxylin-eosin (HE) staining [18]}

The peri-implant periodontal tissue was extracted, fixed with $4 \%$ formaldehyde solution for $24 \mathrm{~h}$, embedded in paraffin and then cut into 3-4 $\mu \mathrm{m}$ sections. The sections were routinely stained with HE, and an optical microscope was used to examine the tissues, including the morphology, quantity, arrangement and continuity of the basement membrane of the cells in the gingival epithelium and gingival sulcus epithelium or pocket epithelium; the morphology, quantity, and arrangement of the lamina propria fibroblasts, collagen fibers, and blood vessels; and the types, quantity and arrangement of inflammatory cells. The sections were evaluated by two professional pathologists using a blinded method to score the inflammatory cell infiltration in the periodontium, and the average value was reported. The standard histopathological scores for the degree of inflammation were as follows: 0 points represented no inflammatory cell infiltration; 1 point suggested a small focal infiltration of local inflammatory cells; 2 points indicated focal and patchy infiltration of inflammatory cells in gingival tissue; and 3 points represented diffuse infiltration of inflammatory cells in gingival tissue [19].

\section{Enzyme-linked immunosorbent assay (ELISA) [20]}

To collect the peri-implant crevicular fluid (PICF), the implant was protected from wetting using a cotton roll, the gum was gently dried with a stream of air, and Whatman $3 \#$ filter paper $(2 \mathrm{~mm} \times 20 \mathrm{~mm})$ was inserted into the peri-implant gingival tissue (mesial, distal, buccal, and lingual/palatal) of the sample. The samples were protected from contamination with blood and saliva, and the wetted area was measured and recorded using a Vernier caliper after $60 \mathrm{~s}$. Subsequently, the dry filter paper was cut off, and the sample was transferred into a prepared Eppendorf (EP) tube with $200 \mu \mathrm{L}$ of phosphate-buffered saline (PBS) containing $0.1 \%$ bovine serum albumin (BSA) $(\mathrm{pH}=7.4)$. The specimens were immediately preserved at $-70^{\circ} \mathrm{C}$ for subsequent analyses. The frozen samples were thawed on ice and assayed according to the instructions of the corresponding ELISA Kits (Siemens AG, Siemensdamm, Germany) to determine the levels of IL-1, IL-6, IL- 8 and TNF- $\alpha$ in the supernatants of the periodontal tissue homogenate.

\section{KARGER}




\section{Cellular Physiology Cell Physiol Biochem 2018:49:610-625 \begin{tabular}{l|l|l} 
and Biochemistry & Dublished online: 29 August, 2018 & $\begin{array}{l}\text { (c) 2018 The Author(s). Published by S. Karger AG, Basel } \\
\text { www.karger.com/cpb }\end{array}$
\end{tabular}}

He et al.: PDTC Inhibits NF- $\mathrm{kB}$ in Peri-Implantitis

\section{Immunohistochemistry [21]}

The periodontal tissue was conventionally fixed, dehydrated, embedded in paraffin, and cut into 5 - $\mu \mathrm{m}$ sections. The samples were then treated with $1 \% \mathrm{H}_{2} \mathrm{O}_{2}$ to block endogenous peroxidase, and the sections were then heated to $97^{\circ} \mathrm{C}$ in antigen-retrieval solution for $15 \mathrm{~min}$ and then cooled. Subsequently, the sample was incubated at room temperature for $60 \mathrm{~min}$ with NF- $\kappa \mathrm{B}$ p65 rabbit antibody (1:100, Abcam Inc., Cambridge, MA, USA), rinsed with distilled water and then placed in the PBS solution. Next, horseradish peroxidase-labeled goat anti-rabbit IgG (1:3000, Santa Cruz Biotechnology, USA) was added to the sample and incubated at $37^{\circ} \mathrm{C}$ for $40 \mathrm{~min}$, rinsed with distilled water and placed in PBS solution. Next, the sample was stained with DAB (MXB Biotechnologies Inc., Fujian, China) for 3 min under a microscope and then rinsed with tap water to terminate the reaction. The sample was then rinsed with distilled water, stained again and sealed. Cells in which the cytoplasm and/or nuclei contained yellow and brown particles were identified as positive cells. Five high-power visual fields of periapical periodontium at different time points were selected for photography. Image-Proplus (version 5.0, media cybernetics, Houston, TX) was employed to calculate the integral optical density (IOD) value, and the average value was reported.

\section{Western blot analysis}

The periodontal tissue of each group was extracted, sliced into small pieces of tissue and placed in the tissue homogenizer. The tissue was combined with a protein lysis solution and phenylmethylsulfonyl fluoride (PMSF) and homogenized to extract the total protein, and the protein concentration was determined using the BCA protein assay kit (Thermo Scientific, Pittsburgh, PA, USA). A total of $30 \mu \mathrm{g}$ total protein was subjected to polyacrylamide gel electrophoresis at a constant voltage of $80 \mathrm{~V}$ for $35 \mathrm{~min}$ and then $120 \mathrm{~V}$ for 45 min. After the electrophoresis, the samples were transferred to a polyvinylidene fluoride (PVDF) membrane (Amersham Pharmacia Biotech, Piscataway, NJ, USA), which was subsequently blocked with 5\% non-fat milk powder at room temperature for $1 \mathrm{~h}$ and then incubated with TLR4 (1:1000, Abcam Inc., Cambridge, MA, USA, ab22048) and beta-actin ( $\beta$-actin) primary antibodies (1:2000, A00702, GenScript, Piscataway, NJ, USA) at $4^{\circ} \mathrm{C}$ overnight. Phosphate-buffered saline (PBST) containing $0.1 \%$ Tween-20 PBS buffer solution was used to wash the membranes 3 times, followed by the addition of a horseradish peroxidase-labeled goat anti-mouse secondary antibody (1:10000, Catalog No. 111-035-003, Jackson Immunol Research, USA) for $1 \mathrm{~h}$ and then 3 washes with PBST. The relative expression of the TLR4 protein was analyzed by gray scale scanning of protein bands using Image-Pro Plus 6.0 software (Media Cybernetics, Bethesda, MD, USA) after development of the optical luminescence (General Electric Company, Schenectady, NY, USA).

\section{Reverse transcription-quantitative polymerase chain reaction (RT-qPCR)}

The total RNA of periodontal tissue was extracted using the TRIzol RNA Extraction Kit (Aidlab Co., Beijing, China). An RNA sample (5 $\mu \mathrm{L}$ ) was removed and diluted 20 times with RNA-free ultrapure water. Then, the absorption values at $260 \mathrm{~nm}$ and $280 \mathrm{~nm}$ were recorded using an ultraviolet spectrophotometer (Thermo Fisher, Waltham, MA, USA), and the concentration and purity of the RNA were detected based on an OD260/OD280 ratio of 1.8-2.0. Reverse transcription of the synthesized cDNA and antisense microRNAs was performed on PCR amplifiers (Thermo Fisher, Waltham, MA, USA), and then ABI7500 RT-qPCR (Thermo Fisher, Waltham, MA, USA) was conducted. The reaction conditions consisted of pre-denaturation at $95^{\circ} \mathrm{C}$ for $10 \mathrm{~min}, 45 \mathrm{PCR}$ cycles of denaturation at $95^{\circ} \mathrm{C}$ for $15 \mathrm{~s}$, annealing at $60^{\circ} \mathrm{C}$ for $1 \mathrm{~min}$, and extension at $72^{\circ} \mathrm{C}$ for $10 \mathrm{~s}$. The primers used in the reaction are shown in Table 1 . The $2^{-\Delta \Delta \mathrm{ct}}$ method was used to evaluate the ratio between the model group and the normal group with $\beta$-actin as the internal reference, and the formula was as follows: $\Delta \Delta \mathrm{CT}=$ $\Delta \mathrm{Ct}_{\text {model group }}-\Delta \mathrm{Ct}_{\text {normal group }}$ and $\Delta \mathrm{Ct}$ $=\mathrm{Ct}_{\text {target gene }}-\mathrm{Ct}_{\beta \text {-actin }}$ [22]. Ct was the number of amplification cycles of real-time fluorescence intensity of the reaction up to the set threshold, and the amplification was presented as the logarithmic growth.

Table 1. The primer sequences for RT-qPCR. Notes: RT-qPCR, reverse transcription-quantitative polymerase chain reaction; TLR4, toll-like receptor 4; NF- $\kappa \mathrm{B}$ p65, nuclear factor-kappaBp65; $\beta$-actin, betaactin; F, forward; R, reverse

\begin{tabular}{lc}
\hline Genes & \multicolumn{1}{c}{ Sequences } \\
\hline \multirow{2}{*}{ TLR4 } & F: 5'- CCTGGAAGGACTGTGCAATT -3' \\
& R: 5'- TGCTTCAGTCTGGTTGTCCC-3' \\
NF-кB p65 & F: 5'- ATGGCAGACGATGATCCCTAC-3' \\
& R:5'- CGGATCGAAATCCCCTCTGTT-3' \\
\multirow{2}{*}{-actin } & F: 5'- GGCATCCTCACCCTGAAGTA-3' \\
& R: 5'- GGGGTGTTGAAGGTCTCAAA-3' \\
\hline
\end{tabular}




\section{Cellular Physiology Cell Physiol Biochem 2018;49:610-625

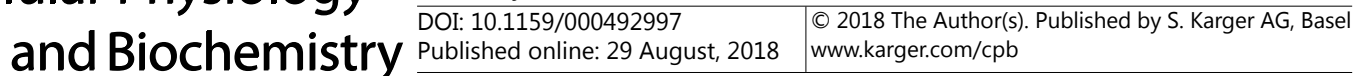

He et al.: PDTC Inhibits NF-кB in Peri-Implantitis

Immunofluorescence assay

The PDLFs of the peri-implantitis model and normal canines were extracted for culturing, and fourth generation PDLFs with good growth were inoculated into 6-well culture plates containing cover glasses. Upon reaching 60\% confluence, the PDLFs were assigned to the normal group (PDLFs from normal canines), the PDLF model (PDLFs from peri-implantitis canines), the PDLF model + LPS [PDLFs from peri-implantitis canines pretreated with $10 \mu \mathrm{g} / \mathrm{mL}$ LPS (Sigma-Aldrich, St. Louis, USA)], the PDLF model + PDTC (PDLFs from peri-implantitis canines pretreated with $100 \mu \mathrm{mol} / \mathrm{mL}$ PDTC), and the PDLF model + LPS + PDTC (PDLFs from peri-implantitis canines pretreated with $10 \mu \mathrm{g} / \mathrm{mL}$ LPS and $100 \mu \mathrm{mol} / \mathrm{mL}$ PDTC for $30 \mathrm{~min}$ ). The cell samples were removed after having been treated according to the above experimental procedures, washed once in precooled PBS, fixed with paraformaldehyde for $30 \mathrm{~min}$ and then washed 5 times with PBS. The samples were then treated with $1 \% \mathrm{H}_{2} \mathrm{O}_{2}$-PBS for 25 min to block endogenous peroxidase and washed 3 times with PBS. The samples were then incubated for 20 min with 0.3\% Triton X-100 (Sigma-Aldrich, St. Louis, USA) to increase the membrane permeability and then washed 3 times with PBS. After incubation with sheep serum for $30 \mathrm{~min}$, anti-NF-кBp65 and anti-TLR4 (each 1:100 dilution in 0.01 M PBS) were added, and the sample was incubated at $4^{\circ} \mathrm{C}$ overnight. The samples were then washed 3 times with PBS (5 min/ time). Next, the secondary antibody (1:100 dilution in 0.01 M PBS) labeled with fluorescein isothiocyanate (FITC) was added and incubated at $37^{\circ} \mathrm{C}$ for $1 \mathrm{~h}$ in the dark, followed by 3 washes with PBS ( $5 \mathrm{~min} /$ time). In addition, a diamidino-2-phenylindole (DAPI) staining solution (Sigma-Aldrich, St. Louis, USA) (1:500 dilution in 0.01 M PBS) was added to the sample, followed by incubation at room temperature for 5-10 min and washing 3 times with PBS ( $5 \mathrm{~min} /$ time). The sample was sealed with $50 \%$ buffered glycerol, and 5 views of each slice were randomly selected to evaluate the localization of TLR4 and NF- $\mathrm{KB}$ p65 protein using a fluorescence microscope (Leica Microsystems Inc. Bannockburn, IL, USA). Immune scoring was conducted using the 13-point immunohistochemical scoring method [23] to determine the expression of TLR4 and NF- $\kappa$ B p65 in each group.

\section{Cell counting kit-8 (CCK-8) assay}

The PDLFs in each group were removed, centrifuged, diluted and resuspended to yield uniform singlecell suspensions. The samples were then inoculated into 96-well plates with $100 \mu \mathrm{L}$ of the cell suspension per well ( 5 replicates/well). PBS $(100 \mu \mathrm{L})$ was added to the other wells to maintain the humidity. A total of five 96-well plates were used for inoculation of the sample, and the samples were cultured in an incubator under $5 \% \mathrm{CO}_{2}$ at $37^{\circ} \mathrm{C}$, followed by transfer of the suspensions at intervals of $24 \mathrm{~h}$. Wells representing each group were randomly removed at $24 \mathrm{~h}, 48 \mathrm{~h}, 72 \mathrm{~h}, 96 \mathrm{~h}$ and $120 \mathrm{~h}$. To each sample, $10 \mu \mathrm{L}$ of CCK-8 reagent was then added, followed by continuous incubation in a $5 \% \mathrm{CO}_{2}$ incubator at $37^{\circ} \mathrm{C}$ for $4 \mathrm{~h}$. The absorbance value in each group was determined by ELISA (Sunrise Remote, TECAN, USA). The mean optical density (OD) value of the 5 wells at a wavelength of $450 \mathrm{~nm}$ was measured. Additionally, an OD value chart was generated with the average absorbance values as the ordinate and the analysis time for the various groups as the abscissa. This graph showed the absorbance values as a function of time for the periodontal fibroblasts in each group.

\section{Flow cytometry}

The cells in each group were detached with PBS containing $2.5 \mathrm{~g} / \mathrm{L}$ trypsin $+0.4 \mathrm{~g} / \mathrm{L}$ ethylenediaminetetraacetic acid (EDTA) but without $\mathrm{Ca}^{2+}$ or $\mathrm{Mg}^{2+}$, collected into 5-mL centrifuge tubes, washed two times with $2.5 \mathrm{~mL}$ PBS (centrifugation at 800-1000 r/min for $5 \mathrm{~min}$ ), and the supernatant was removed. The cells were then mixed with PBS $(1 \mathrm{~mL})$. Absolute ethanol $(2 \mathrm{~mL})$ was added and the suspension was mixed by oscillation, sealed with paraffin, and then refrigerated at $4^{\circ} \mathrm{C}$. The subsequent procedures on the cells were performed after fixation for $15 \mathrm{~d}$. The cell concentration was adjusted to $5 \times 10^{5}-1 \times 10^{6} \mathrm{~mL}^{-1}$ for these evaluations. After mixing, the cells in each group were transferred to duplicate flow tubes, and the Annexin V-FITC apoptosis detection kit (Biovision, Mountain View, CA, USA) was employed to detect cell apoptosis. A Becton Dickinson FACSCalibur (Guave, USA) was used to detect apoptosis and the percent of the cells that were in each phase of the cell cycle in each group. 


\section{Cellular Physiology Cell Physiol Biochem 2018;49:610-625 \begin{tabular}{ll|l} 
and Biochemistry & $\begin{array}{l}\text { DOI: 10.1159/000492997 } \\
\text { Published online: 29 August, } 2018\end{array}$ & $\begin{array}{l}\text { (c) } 2018 \text { The Author(s). Published by S. Karger AG, Basel } \\
\text { www.karger.com/cpb }\end{array}$
\end{tabular}}

Statistical analysis

The data were analyzed using the Statistical Package for the Social Sciences (IBM Corp Armonk, NY, USA) software 21.0. The data are presented as the means \pm standard deviation (SD). The $t$ test was used for comparison between two groups. Multiple groups were compared using multivariate analysis of variance. A level of $p<0.05$ was considered to be statistically significant, and $p<0.01$ indicated that the difference was highly significant.

\section{Results}

The histological changes in the periodontal tissue of the various treatment groups

To evaluate the effect of PDTC treatment on inflammatory infiltration in peri-implantitis, we analyzed the histological changes in the periodontal tissue in the various treatment groups using HE staining. The results are shown in Fig. 1A. The gingival epithelium of the normal control group was normal and integrated without ulcerous phenomena. A low level of inflammatory cell infiltration was observed in the subepithelial connective tissue with orderly fibers of the periodontal membrane. However, the gingival epithelium in the model group had ulcerous phenomena with attachment loss, and the gingival fibers exhibited irregular arrangements with severe chronic inflammatory cell infiltration. Moreover, the model group showed alveolar bone resorption in the alveolar crest, osteoclast and bone resorption in the alveolar region, and a sparser arrangement of the trabeculae. The gingival epithelium in the PDTC group showed no ulcerous phenomena or attachment loss, but a low level of inflammatory cell infiltration in the subepithelial connective tissue was observed. These results suggested a clear reduction of the inflammation. As shown in Fig. 1B, all periodontal histological scores for the PDTC $(5.67 \pm 0.52)$ and model $(10.00 \pm 0.63)$ groups were significantly higher than those in the normal group $(1.83 \pm 0.75)(p<0.05)$, but the periodontal histological scores for the PDTC group were significantly lower than those in the model group $(p<0.05)$. These results revealed that PDTC could inhibit the inflammatory response in periodontal tissue.

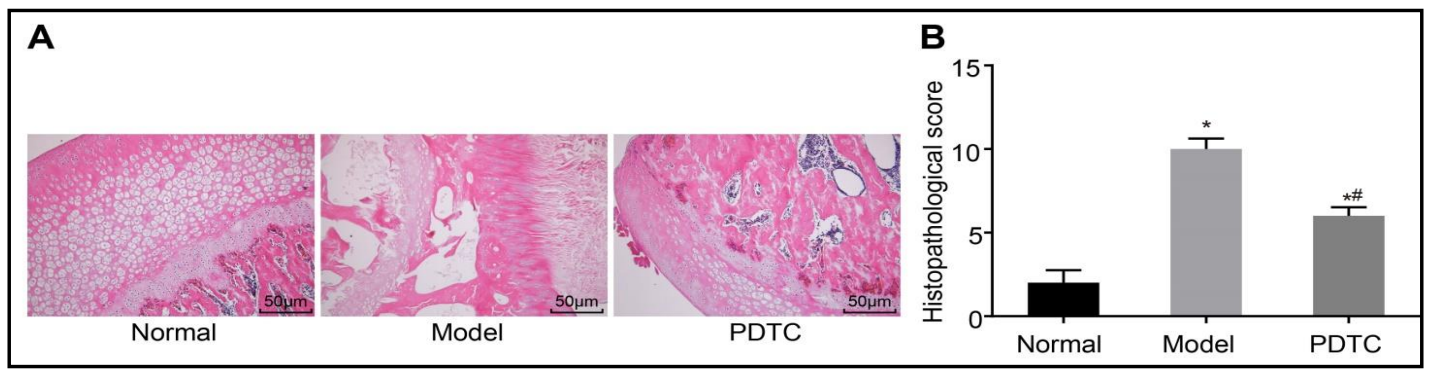

Fig. 1. The histological changes in periodontal tissue examined using hematoxylin-eosin staining $(n=6)$. Panel (A): hematoxylin-eosin (HE) stained sections $(\times 200)$ of periodontal tissue in the normal, model and PDTC groups; Panel (B): graph of the periodontal histological scores in each group; *, $\mathrm{p}<0.05$ vs. the normal group; ${ }^{\#}, \mathrm{p}<0.05$ vs. the model group; PDTC, pyrrolidine dithiocarbamate.

Table 2. Comparison of levels of IL-1, IL-6, IL-8 and TNF- $\alpha$ in periodontal tissue of each group (pg/mL, $n=6)$. Notes: *, p < 0.05 vs. the normal group; *, p < 0.05 vs. the model group; PDTC, pyrrolidine dithiocarbamate; IL-1, interleukin-1; IL-6, interleukin-6; IL-8, interleukin-8; TNF- $\alpha$, tumor necrosis factor alpha

\begin{tabular}{lcccc}
\hline Groups & IL-1 & IL-6 & IL-8 & TNF- $\alpha$ \\
\hline Normal & $5.16 \pm 3.10$ & $5.22 \pm 0.57$ & $25.30 \pm 13.30$ & $10.23 \pm 3.24$ \\
Model & $85.14 \pm 2.13^{*}$ & $450.13 \pm 23.12^{*}$ & $421.18 \pm 14.28^{*}$ & $120.48 \pm 2.67^{*}$ \\
PDTC & $41.35 \pm 3.68^{* \#}$ & $211.56 \pm 12.48^{* \#}$ & $213.25 \pm 23.21^{* \#}$ & $63.80 \pm 9.30^{* \#}$ \\
\hline
\end{tabular}




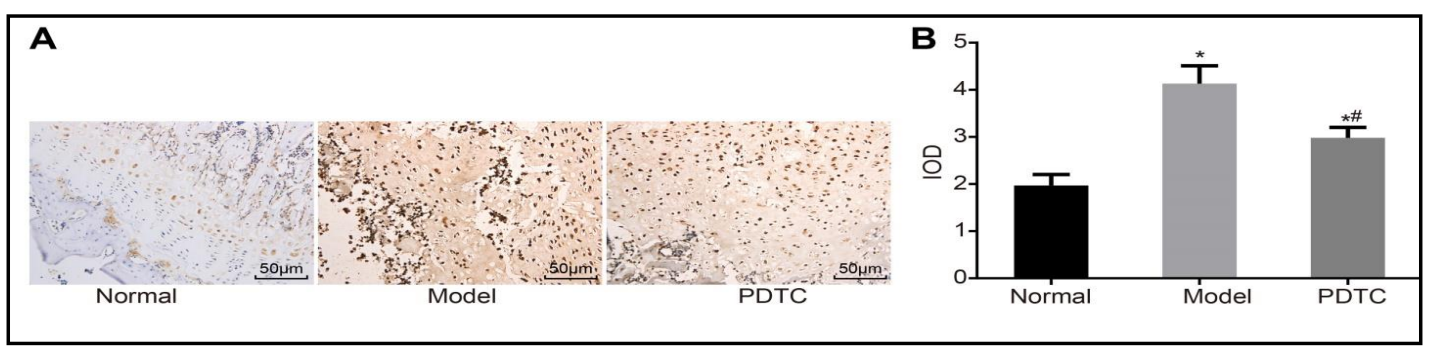

Fig. 2. $N F-\kappa B$ p65 expression in the periodontal tissue as indicated by immunohistochemistry $(n=6)$. Panel (A): micrographs of the periodontal tissue in each group showing the immunohistochemistry for NF- $\kappa B$ p65 $(\times 200)$; Panel (B): graph of the IOD values of the periodontal tissues in each group; ${ }^{*}, \mathrm{p}<0.05$ vs. the normal group; ${ }^{\#}, \mathrm{p}<0.05$ vs. the model group; PDTC, pyrrolidine dithiocarbamate; NF- $\kappa B$ p 65 , nuclear factor-kappa Bp65; IOD, integral optical density.

PDTC treatment exhibits an inhibitory effect on the release of pro-inflammatory cytokines in vivo

We used ELISA to measure the levels of IL-1, IL-6, IL-8 and TNF- $\alpha$ to evaluate the effect of PDTC treatment on the release of pro-inflammatory cytokines in periodontal tissue during periimplantitis. As shown in Table 2, compared with the normal group, the homogenate supernatants of the periodontal tissues from the PDTC group and the model group demonstrated significantly higher levels of IL-1, IL-6, IL-8 and TNF- $\alpha$ (all $p<0.05$ ). Additionally, the levels of IL-1, IL-6, IL-8 and TNF- $\alpha$

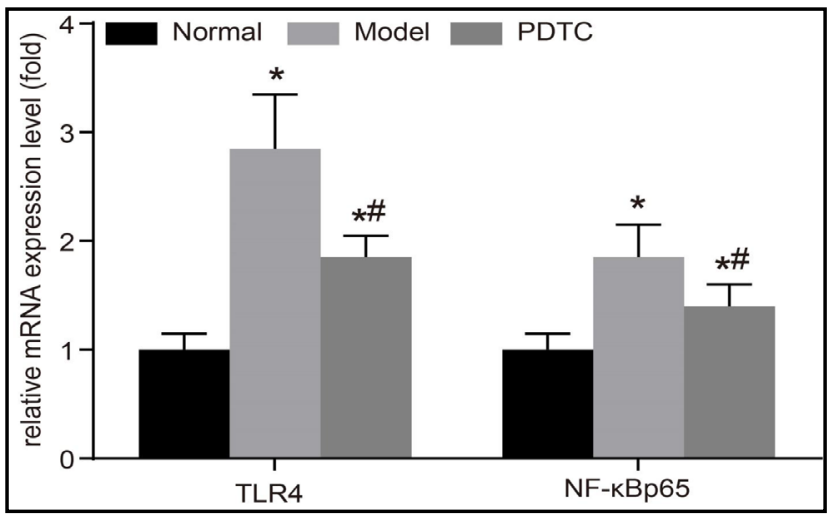

Fig. 3. The mRNA expression of TLR 4 and NF- $\kappa B$ p 65 in canine periodontal tissues measured using RT-qPCR $(n=6) .{ }^{*}, p<0.05$ vs. the normal group; \#, p<0.05 vs. the model group; PDTC, pyrrolidine dithiocarbamate group; TLR4, toll-like receptor 4; NF-кB p65, nuclear factor-kappa B p65; RT-qPCR, reverse transcription-quantitative polymerase chain reaction. in the homogenate supernatants in the PDTC group were clearly lower than those in the model group (all $p<0.05$ ) but higher than those in the normal group (all $p<0.05$ ). These data showed that inflammation could cause increases in the levels of IL-1, IL- 6 , IL-8 and TNF- $\alpha$ in the homogenate supernatant of periodontal tissues, but PDTC could inhibit the secretion of IL-1, IL-6, IL-8 and TNF- $\alpha$.

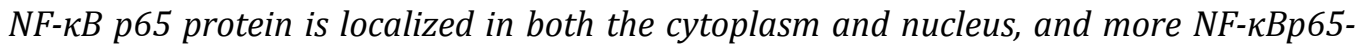
positive cells are found in periodontal tissues

To evaluate alterations in the NF- $\kappa B$ p65 expression and the effect of PDTC treatment on NF- $\mathrm{KB}$ p65 expression in periodontal tissues, we performed immunohistochemistry and scored the results. NF- $\mathrm{KB}$ p65 expression was localized in cytoplasm and nuclei in the periodontal tissue, mainly in the periodontal epithelial and inflammatory cells. The NF- $\kappa B$ p65 in the periodontal tissue showed a low IOD value in the normal group $(1.97 \pm 0.23)$, but the expression was strongly positive in the model ( $4.13 \pm 0.38)$ and PDTC (2.98 \pm 0.22$)$ groups. Furthermore, as shown in Fig. 2, the expression intensity in the inflammatory epithelium was higher than in non-inflammatory epithelium, especially in the model group. Additionally, the IOD value for the model group was significantly higher than that for the PDTC group $(p<0.05)$, and all the IOD values for the model and PDTC groups were clearly higher than that of the normal group (all $p<0.05$ ). These findings indicated that NF- $\kappa \mathrm{B}$ p65 was upregulated in canine periodontal tissues and PDTC could suppress the expression of NF- $\kappa$ B p65. 
PDTC treatment suppresses the expression of NF- $\kappa B$ p 65 and TLR4 in vivo

Subsequently, we determined the mRNA levels of NF- $\kappa B$ p 65 and TLR4 in the periodontal tissues using RT-qPCR. Fig. 3 shows that in the normal group, the mRNA levels of NF- $\kappa B$ p65 and TLR4 were $1.00 \pm 0.15$ and $1.00 \pm 0.15$, respectively. In the model group, the mRNA levels of NF- $\mathrm{BB}$ p 65 and TLR4 were $2.85 \pm 0.50$ and $1.85 \pm 0.30$, respectively. In the PDTC group, the mRNA levels of NF- $\kappa B$ p65 and TLR4 were $1.85 \pm 0.20$ and $1.30 \pm 0.20$, respectively. The mRNA levels of TLR4 and NF- $\kappa B$ p65 in the model and PDTC groups were apparently higher than those in the control group (both $p<0.05$ ), but compared with the model group, the mRNA expression levels of TLR4 and NF- $\kappa$ B p65 in the PDTC group were clearly decreased (both $p<0.05$ ). These results indicated that NF- $\kappa B$ p 65 and TLR4 were upregulated in canine periodontal tissues, and PDTC could suppress the expression of NF- $\kappa$ B p65 and TLR4.

\section{PDTC treatment decreases the TLR4 protein level induced by inflammation}

As shown in Fig. 4, the levels of the TLR4 protein were $1.00 \pm 0.13$ in the normal group, $2.13 \pm 0.30$ in the model group, and $1.45 \pm 0.26$ in the PDTC group. The protein levels of TLR4 in the periodontal tissues in the model and PDTC groups were significantly higher than that in the normal group $(p<0.05)$, and the TLR4 protein level in the PDTC group was clearly lower than that in the model group $(p<0.05)$ but higher than that in the normal group $(p<$ $0.05)$. These results showed that inflammation could increase the TLR4 protein expression in canine periodontal tissue, and PDTC could inhibit the increase in TLR4 protein expression induced by inflammation.

\section{PDTC inhibits the LPS-induced release of pro-inflammatory cytokines in vitro}

To study the mechanism of the PDTC and NF- $\kappa B$ in the inflammatory response of PDLFs in peri-implantitis, the levels of IL-1, IL-6, IL-8 and TNF- $\alpha$ in PDLFs were determined by ELISA. As shown in Table 3, compared with the PDLF normal group, the IL-1 level was increased 16.5-, 32.2-, 9.9-, and 14.3-fold in the PDLF model, PDLF model + LPS, PDLF model + PDTC, and PDLF model + LPS + PDTC groups, respectively. Compared with the PDLF normal group, the IL-6 level was increased 86.23-, 138.20-, 46.28-, and 82.78-fold in the PDLF model, PDLF model + LPS, PDLF model + PDTC, and PDLF model + LPS + PDTC groups, respectively. Compared with that in the PDLF normal group, the IL-8 level was increased 16.65-, 24.03-, 8.42-, and 14.81-fold in the PDLF model, PDLF model +

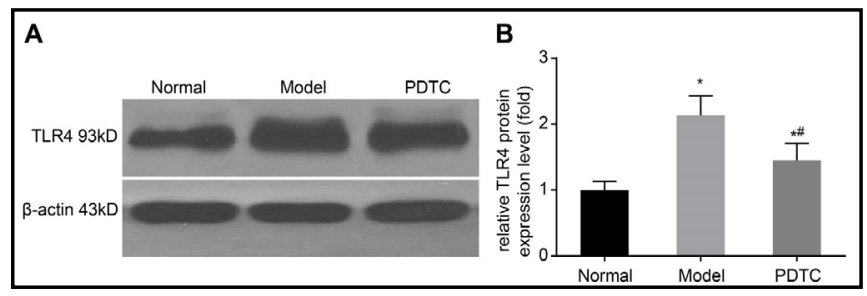

Fig. 4. TLR4 protein levels in canine periodontal tissues in each group as indicated by western blot analysis $(n=6)$. Panel $(A)$ : images of the western blot analysis of the TLR4 protein in the periodontal tissues of each group; Panel (B): graph of the relative gray scales of TLR4 expression in each group; *, $\mathrm{p}<0.05 \mathrm{vs}$. the normal group; \#, $\mathrm{p}<0.05$ vs. the model group; PDTC, pyrrolidine dithiocarbamate; TLR4, Toll-like receptor 4 ; $\beta$-actin, beta-actin.

Table 3. The levels of IL-1, IL-6, IL-8 and TNF- $\alpha$ in cell supernatant of each group (pg/mL, $n=5)$. Notes: $5 \times 10^{5}$ cells in each group; *, p < 0.05 vs. the PDLFs normal group; \#, p < 0.05 vs. the PDLF model group; LPS, lipopolysaccharide; PDTC, pyrrolidine dithiocarbamate; IL-1, interleukin-1; IL-6, interleukin-6; IL-8, interleukin-8; TNF- $\alpha$, tumor necrosis factor alpha; PDLFs, periodontal ligament fibroblasts

\begin{tabular}{lcccc}
\hline Group & IL-1 & IL-6 & IL-8 & TNF- $\alpha$ \\
\hline PDLFs normal & $5.16 \pm 3.10$ & $5.22 \pm 0.57$ & $25.30 \pm 13.30$ & $10.23 \pm 3.24$ \\
PDLFs model & $85.14 \pm 2.13^{*}$ & $450.13 \pm 23.12^{*}$ & $421.18 \pm 14.28^{*}$ & $120.48 \pm 2.67^{*}$ \\
PDLFs model + LPS & $166.00 \pm 4.29^{* \#}$ & $721.45 \pm 65.12^{* \#}$ & $607.92 \pm 81.70^{* \#}$ & $185.23 \pm 8.10^{* \#}$ \\
PDLFs model + PDTC & $51.35 \pm 3.68^{* \#}$ & $241.56 \pm 12.48^{* \#}$ & $213.25 \pm 23.21^{* \#}$ & $83.80 \pm 9.30^{* \#}$ \\
PDLFs model + LPS + PDTC & $73.77 \pm 9.28^{*}$ & $432.10 \pm 51.12^{*}$ & $374.60 \pm 53.62^{*}$ & $105.12 \pm 8.12^{*}$ \\
\hline
\end{tabular}




\section{Cellular Physiology Cell Physiol Biochem 2018;49:610-625 \begin{tabular}{ll|l} 
DOI: 10.1159/000492997 & $\begin{array}{l}\text { O 2018 The Author(s). Published by S. Karger AG, Basel } \\
\text { www.karger.com/cpb }\end{array}$
\end{tabular}

LPS, PDLF model + PDTC, and PDLF model + LPS + PDTC groups, respectively. Compared with that in the PDLF normal group, the TNF- $\alpha$ level was increased 11.8-, 18.1-, 8.2-, and 10.3-fold in the PDLF model, PDLF model + LPS, PDLF model + PDTC, and PDLF model + LPS + PDTC groups, respectively (all $p<0.05$ ). These findings indicated that the inflammation in the periodontal implant could increase the secretion of IL-1, IL-6, IL-8 and TNF- $\alpha(p<0.05)$. Compared with those in the PDLF model group, the levels of IL-1, IL-6, IL-8 and TNF- $\alpha$ were clearly increased in the PDLF model + LPS group $(p<0.05)$ but were apparently decreased in the PDLF model + PDTC group $(p<0.05)$. Additionally, the levels of IL-1, IL-6, IL-8 and TNF- $\alpha$ in the PDLF model + LPS + PDTC group were not significantly different from those of the PDLF model group $(p>0.05)$. These results revealed that PDTC could prevent the LPSinduced increases in the levels of IL-1, IL-6, IL-8 and TNF- $\alpha$.

\section{PDTC inhibited the LPS-induced upregulation of NF- $K B p 65$ and TLR4 in PDLFs in vitro}

The detailed regulatory effect of PDTC on TLR4 and NF- $\kappa B$ was studied in PDLFs using the immunofluorescence assay. As shown in Fig. 5, the TLR4 in the PDLF normal group was mainly expressed in the PDLF cytoplasm, as indicated by the green fluorescence, but it was not expressed in the nucleus. The green fluorescence in all of the other groups was stronger than that in the PDLF normal group (all $p<0.05$ ), and TLR4 was not expressed in the nucleus. Compared with the PDLF model group, the expression of TLR4 was increased in the cytoplasm in the PDLF model + LPS group $(p<0.05)$, and the green TLR4 fluorescence was reduced in the cytoplasm in the PDLF model + PDTC group $(p<0.05)$. There were no obvious differences in TLR4 expression in the PDLF model + LPS + PDTC group compared with the PDLF model group $(p>0.05)$. NF- $\kappa B$ p65, which is an important nuclear transcription factor, was generally present throughout the cytoplasm in an inactive state. NF- $\kappa \mathrm{B}$ p65 was highly expressed in the cytoplasm in the PDLF normal group and showed strong green fluorescence in the nuclei of the cells in the PDLF model and PDLF model + LPS groups. Moreover, the PDLF model + LPS group showed stronger green fluorescence than the PDLF model group, and the green fluorescence in the cytoplasm was weaker. However, the fluorescence of NF-

Fig. 5. Expression of TLR4 and NF- $\kappa B$ p65 in the PDLFs in each group as indicated by immunofluorescence $(\mathrm{n}=5)$. Panel (A): micrographs showing the expression of TLR4 in the PDLFs in each group; Panel (B): micrographs of the expression of NF- $\kappa B$ p65 in the PDLFs in each group; Panels (C) and (D): graphs of the ratios of the immunofluorescence in the cytoplasm and nuclei for TLR4 expression and NF- $\mathrm{kB}$ p65 expression; *, $\mathrm{p}<0.05$ vs. the PDLFs normal group; \#, $\mathrm{p}<0.05$ vs. the PDLFs model group; LPS, lipopolysaccharide; NF- $\kappa B$ p65, nuclear factor-kappa B p65; PDTC, pyrrolidine dithiocarbamate; PDLFs, periodontal ligament fibroblasts.

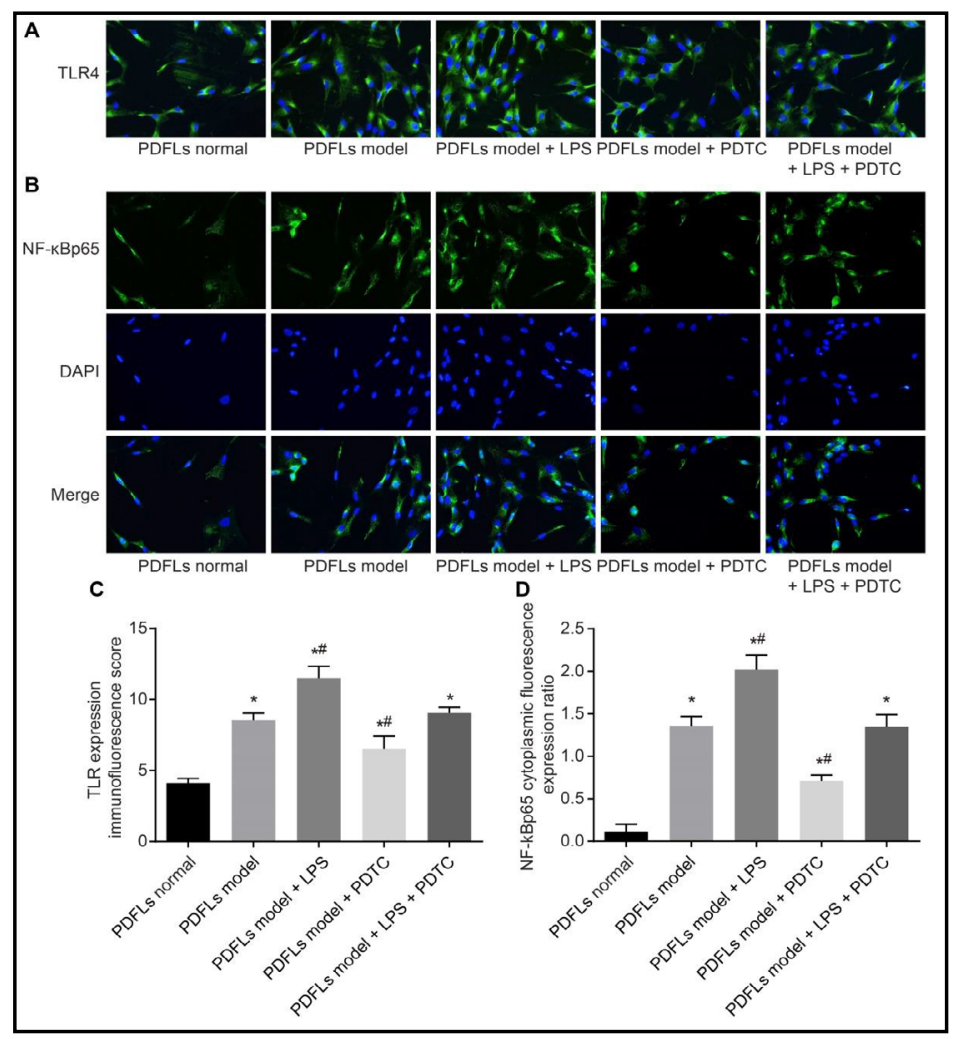




\section{Cellular Physiology Cell Physiol Biochem 2018;49:610-625 \begin{tabular}{ll|l} 
DOI: 10.1159/000492997 & $\begin{array}{l}\text { O } 2018 \text { The Author(s). Published by S. Karger AG, Basel } \\
\text { www.karger.com/cpb }\end{array}$ \\
\hline
\end{tabular}

$\kappa \mathrm{B}$ p65 in the nuclei was obviously reduced after PDTC pretreatment, although the strong green fluorescence persisted in the cytoplasm. Furthermore, the NF- $\kappa$ B p65 expression in the nuclei of the cells that had been simultaneously exposed to LPS and PDTC did not differ from that of the PDLF model group. These results demonstrated that PDTC inhibited the LPSinduced upregulation of NF- $\mathrm{kBp} 65$ and TLR4.

\section{PDTC promotes the proliferation of PDLFS}

In the following experiments, we mainly evaluated the effects of PDTC on the biological functions of PDLFs in vitro and the underlying mechanism. Initially, we performed the CCK-8 assay to assess the viability of PDLFs. As shown in Fig. 6, compared with the PDLF normal group, the cell proliferation ability was apparently reduced in the other groups within $0-120 \mathrm{~h}(p$ $<0.05$ ). Additionally, compared with the PDLF model group, the cell proliferation ability had clearly decreased in the PDLF model + LPS

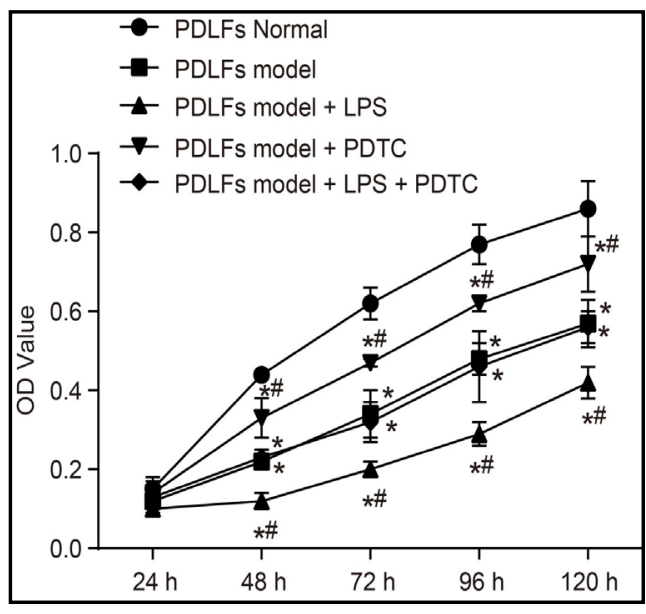

Fig. 6. CCK-8 assay to measure the cell proliferation ability in each group $(\mathrm{n}=5) .{ }^{*}$, $\mathrm{p}<0.05$ vs. the PDLFs normal group; \#, $\mathrm{p}<0.05$ vs. the PDLFs model group; PDTC, pyrrolidine dithiocarbamate; LPS, lipopolysaccharide; CCK, cell counting kit; PDLFs, periodontal ligament fibroblasts. group $(p<0.05)$, indicating that in the PDLF model, the addition of LPS could inhibit the proliferation of canine PDLFs. The cell growth curve became significantly steeper in the PDLF model + PDTC group $(p<0.05)$, but there was no difference between the PDLF model + LPS group and the PDLF model group ( $p>0.05$ ). These findings implied that PDTC could prevent the inhibitory effect in the PDLF model + LPS on cell proliferation of periodontal fibroblasts.

\section{PDTC promotes cell cycle progression and inhibits cell apoptosis in PDLFS}

We further investigated the effects of PDTC on cell cycle progression and cell apoptosis in PDLFs using flow cytometric analysis of Annexin V-FITC staining. As shown in Fig. 7A, the proportions of cells in S phase in the PDLF normal, PDLF model, PDLF model + LPS, PDLF model + PDTC, and PDLF model + LPS + PDTC groups were $49.83 \pm 1.46 \%, 27.40 \pm 0.71 \%$, $17.24 \pm 0.72 \%, 37.76 \pm 0.14 \%$, and $25.86 \pm 0.65 \%$, respectively. Compared with the PDLF normal group, cell cycle progression in the other groups was blocked, and the proportions of cells in S phase were lower $(p<0.05)$. Compared with the PDLF model group, the proportion of cells in S phase decreased in the PDLF model + LPS group $(p<0.05)$, but the cells in $\mathrm{G}_{0} / \mathrm{G}_{1}$ phase increased. Additionally, the proportion of cells in S phase in the PDLF model + PDTC group was significantly higher than that in the PDLF model group $(p<0.05)$. Moreover, the proportions of cells in S phase did not differ between the PDLF model + LPS + PDTC group and the PDLF model group ( $p>0.05$ ) (Fig. 7; Table 4). These findings suggested that PDTC promoted cell cycle progression by acting as a blockade.

As shown in Fig. 7B, the flow cytometric analysis showed that the apoptosis rates in the PDLF normal, PDLF model, PDLF model + LPS, PDLF model + PDTC, and PDLF model + LPS + PDTC groups were $6.23 \pm 0.06 \%, 25.52 \pm 0.90 \%, 49.63 \pm 1.19 \%, 13.15 \pm 0.79 \%$, and 24.91 $\pm 1.53 \%$, respectively. The lower left quadrants in the figure show the live cells, the upper left quadrants show the dead cells, the lower right quadrants show the early apoptotic cells, and the upper right quadrants show the late apoptotic cells. The quantitative analysis results are shown in Table 4. Compared with that in the PDLF normal group, the cell apoptosis rate in the other groups apparently increased $(p<0.05)$. Compared with that in the PDLF model group, the cell apoptosis rate in the PDLF model + LPS group significantly increased $(p<$ $0.05)$, while the apoptosis rate in the PDLF model + PDTC group clearly increased $(p<0.05)$, and there was no obvious difference between the PDLF model + LPS + PDTC group and the 
PDLF model group ( $p>0.05$ ). The results showed that apoptosis was induced by the PDLF model + LPS in implant periodontitis in canines, but PDTC inhibited the PDLF apoptosis and relieved implant periodontitis in canines.

Table 4. The cell cycle distribution and cell apoptotic rate in each group. Notes: ${ }^{*}, \mathrm{p}<0.05 \mathrm{vs}$. the PDLFs normal group; \#, p < 0.05 vs. the PDLFs model group; LPS, lipopolysaccharide; PDTC, pyrrolidine dithiocarbamate; PDLFs, periodontal ligament fibroblasts

\begin{tabular}{|c|c|c|c|c|}
\hline \multirow{2}{*}{ Group } & \multicolumn{3}{|c|}{ Cell cycle distribution } & \multirow{2}{*}{ Cell apoptosis rate } \\
\hline & $\mathrm{G}_{0} / \mathrm{G}_{1}$ & $\mathrm{G}_{2} / \mathrm{M}$ & $\mathrm{S}$ & \\
\hline PDLFs normal & $37.61 \pm 0.37$ & $12.56 \pm 1.13$ & $49.83 \pm 1.46$ & $6.23 \pm 0.06$ \\
\hline PDLFs model & $48.95 \pm 0.59^{*}$ & $26.65 \pm 1.30^{*}$ & $27.40 \pm 0.71^{*}$ & $25.52 \pm 0.90 *$ \\
\hline PDLFs model + LPS & $65.77 \pm 1.39 * \#$ & $16.99 \pm 0.98^{* \#}$ & $17.24 \pm 0.72 * \#$ & $49.63 \pm 1.19 * \#$ \\
\hline PDLFs model + PDTC & $42.18 \pm 1.02^{* \#}$ & $20.07 \pm 1.13^{* \#}$ & $37.76 \pm 0.14^{* \#}$ & $13.15 \pm 0.79 * \#$ \\
\hline PDLFs model + LPS + PDTC & $50.56 \pm 0.81 *$ & $23.58 \pm 0.17^{*}$ & $25.86 \pm 0.65^{*}$ & $24.91 \pm 1.53^{*}$ \\
\hline
\end{tabular}

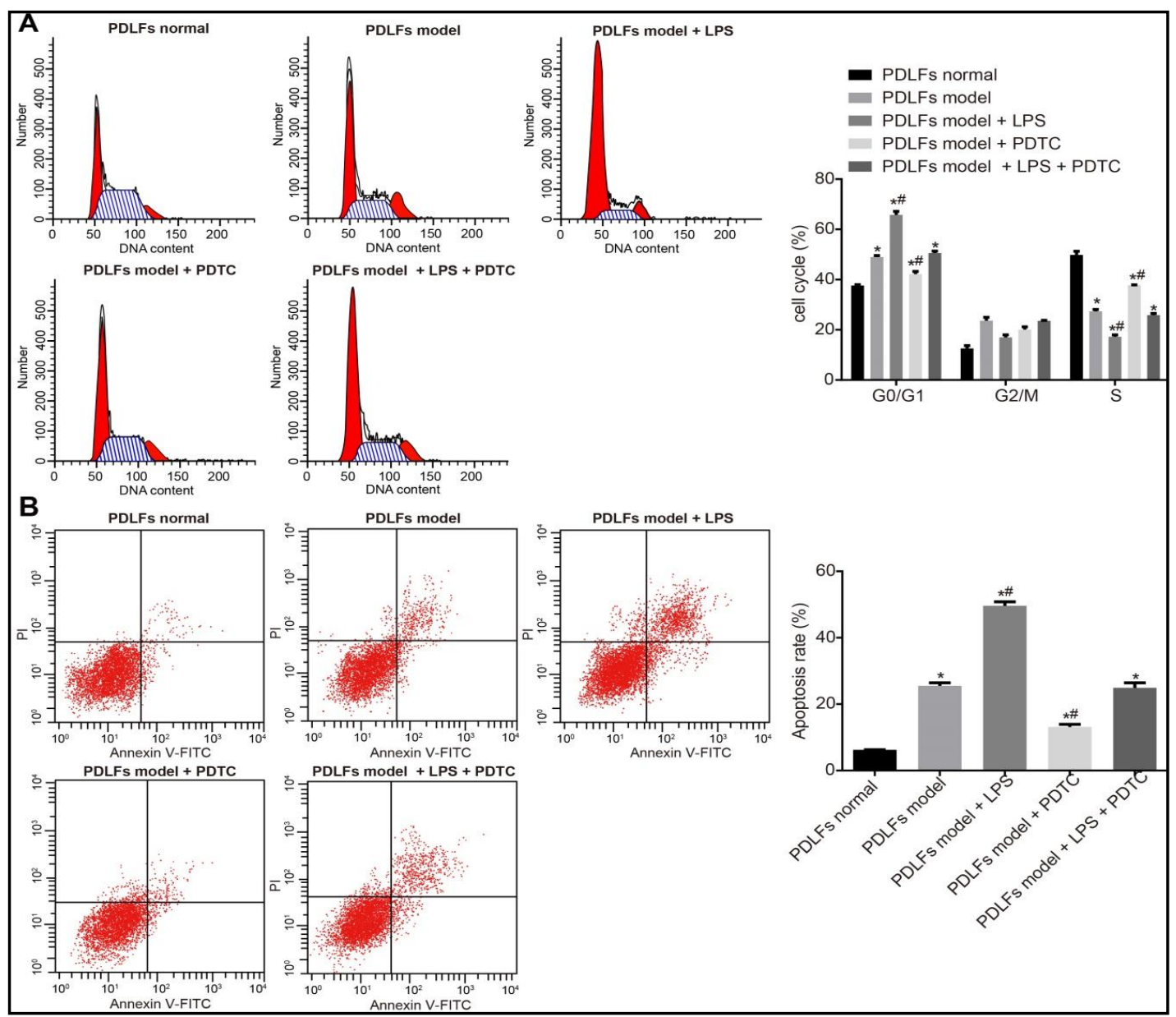

Fig. 7. Cell cycle progression and cell apoptosis in each group as indicated by flow cytometry $(n=5)$. Panel (A): diagrams of cell cycle distribution in each group; Panel (B): diagrams of cell apoptosis rate in each group; LPS, lipopolysaccharide; PDTC, pyrrolidine dithiocarbamate; PDLFs, periodontal ligament fibroblasts. 


\section{Cellular Physiology Cell Physiol Biochem 2018:49:610-625

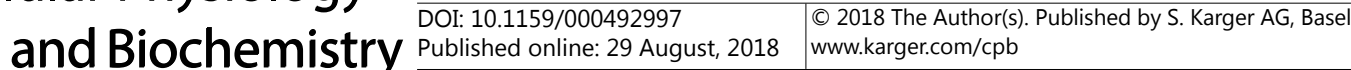

He et al.: PDTC Inhibits NF- $\mathrm{kB}$ in Peri-Implantitis

\section{Discussion}

In addition to the effective short-term outcomes of peri-implantitis that have been shown in many studies, short-term disease resolution, recurrence or progression of disease and implant loss despite treatment have also been reported [24]. One study clearly demonstrated that PDTC-mediated protection against the activation of NF- $\kappa \mathrm{B}$ inhibited the processes of chronic and acute inflammation [25]. In this context, our study elucidated the effect of PDTC on NF- $\kappa \mathrm{B}$ in a canine model of peri-implantitis, and we concluded that PDTC promotes PDLF proliferation and inhibits PDLF apoptosis to suppress inflammation through the inhibition of the NF- $\kappa B$ and inflammatory cytokine expression in a canine model of periimplantitis. Significant increases in the levels of IL-1, IL-6, IL-8 and TNF- $\alpha$ were observed in peri-implantitis. A previous study has reported that an IL-1 polymorphism alone could not be regarded as a risk element for bone loss, but together with smoking, the polymorphism was highly related to peri-implant bone loss [26]. Additionally, proinflammatory cytokines (IL$1 \beta$ and TNF- $\alpha$ ) and chemokines (IL-8 and MIP- $1 \alpha$ ) act as markers of the peri-implant tissue condition. Specifically, healthy patients showed apparently lower concentrations of IL-1 $\beta$, IL8, TNF- $\alpha$ and MIP- $1 \alpha$ in the peri-implant crevicular fluid (PICF) than groups with mucositis [27]. Moreover, Severino VO et al. demonstrated that in patients with peri-implantitis, there are increases in IL-6 and IL-8, which may induce the production of other inflammatory cytokines and thereby contribute to the pathogenesis of bone loss in peri-implantitis [28]. In addition, the results of our study indicated that PDTC could prevent the LPS-induced effects on inflammatory cytokines such as TNF- $\alpha$, IL-1 $\beta$, IL-8, and IL-6. Accumulating evidence has demonstrated that LPS induces the release of proinflammatory cytokines such as TNF- $\alpha$, IL-1 $\beta$, IL-8, and IL-6 $[29,30]$. In human rheumatoid arthritis fibroblast-like synoviocytes, the production of IL-1 $\beta$, IL- 6 and IL- 8 that was induced by TNF- $\alpha$ was decreased by PDTC (a chemical inhibitor of NF- $\kappa B$ ) through the inhibition of the NF- $\kappa B$ signaling pathway [31]. It has been reported that PDTC suppresses the subsequent inflammatory activation [32]. For instance, PDTC has also been shown to decrease the plasma levels of IL- $1 \beta$ and TNF- $\alpha$ in atherosclerotic subjects [33], which is consistent with our findings.

Another important finding was that PDTC treatment decreased the expression of TLR4 and NF-kB p65. TLR4 is a constituent of the innate immune system that recognizes a varied group of molecular structures such as LPS from gram-negative bacteria. TLR4 signaling ultimately results in the reduction of cytokine levels and activation of NF- $\mathrm{KB}$ (the transcription factor) [34]. Additionally, one study showed that the TLR4 signaling pathway mediated the proinflammatory immune response to cobalt-alloy particles [35]. The level of the receptor activator of NF- $\kappa B$ was apparently increased in samples from patients with peri-implantitis compared with healthy implants [36]. The endotoxin LPS, a molecule found in the outer membrane of bacteria, can trigger stimulation of macrophages and microglial cells by activating various signal transduction pathways including NF- $\kappa \mathrm{B}$ [37]. It is known that LPS specifically binds to TLR4 [38]. Accumulating evidence has proved that LPS is the specific ligand of TLR4 [39]. The effects of activated TLR4 are mediated by both MyD88dependent and independent signal pathways. MyD88 interacts with the death domain of IRAK4 and transmits the signal to the IL- 1 receptor-associated kinase family, which triggers a phosphorylation cascade and activates NF- $\kappa \mathrm{B}$; then, the activated NF- $\kappa \mathrm{B}$ is translocated into the nucleus and induces the expression of inflammatory genes and the release of a large number of inflammatory mediators [40]. Therefore, LPS can lead to the high expression of inflammatory factors via TLR4, and these highly expressed inflammatory factors can contribute to cell inflammatory death $[41,42]$. Furthermore, PDTC reduced the LPS-induced kidney injury of systemic lupus erythematosus-prone MRL/lpr mice by suppressing the NF$\kappa \mathrm{B}$ signaling pathway [43]. Ozcan L et al. found that in rats to which PDTC was administered, the inducible nitric oxide synthase and NF- $\kappa B$ p65 expression levels were clearly reduced compared with those in the control group [44]. In addition, as reflected in our study, PDTC inhibited the expression of TLR4 and NF- $\mathrm{KB}$ p65. 
Furthermore, we also demonstrated that PDTC may be a factor that contributes to a reduction in the cell proliferation ability and the proportion of cells in $\mathrm{S}$ phase whereas it increases in cell apoptosis rate. PDTC, an inhibitor of NF- $\mathrm{BB}$ activation, can prevent the inflammatory injury induced by LPS, decrease the inflammatory response, and suppress the cell cycle arrest and apoptosis. LPS is a product of gram-negative bacteria that can cause an immune reaction in vivo $[45,46]$. PDTC might be responsible for the suppressive effect on NF- $\kappa B$-related gene expression [47]. Additionally, TLR4 siRNA modulated cell migration, proliferation, and invasion by inhibiting the expression of a cholesterol acyltransferase 1 [48]. TLR4 is an extracellular pattern recognition receptor that can be activated by LPS. Meanwhile, the nucleotide-binding oligomerization domain (NOD), an intracellular pattern recognition receptor can also be activated. Activated NOD and TLR4 can lead to the activation of inflammatory cells and a process of cell death that is mediated by Caspase- 1 or Caspase- 3 . This process was named pyroptosis [41, 42]. It has been reported that NF- $\kappa B$ inhibits the proliferation and modulates the progression of lens epithelial cells [49]. In hippocampal neurons, treatment with TLR4 antibody, bpV(pic), or PDTC decreased the LPS-induced nuclear translocation of NF- $\kappa B$ and resulted in the down-regulation of TNF- $\alpha$ and IL- $1 \beta$ expression [50], which revealed that the TLR4-mediated NF- $\kappa B$ signaling pathway is associated with the activation of a neuroinflammatory response. In human acute monocytic leukemia, anti$\beta 2 \mathrm{GPI} / \beta 2 \mathrm{GPI}$ stimulates activation of THP- 1 cells (an acute monocytic leukemia cell line) by inducing IL-6, IL-8 and TNF- $\alpha$ expression through the TLR4/MD-2/MyD88 and NF- $\kappa B$ signaling pathways [51]. Uric acid (UA) can induce epithelial mesenchymal transition (EMT) in renal tubular epithelial cells through the activation of the TLR4/NF- $\mathrm{BB}$ signaling pathway, and the targeted intervention of the TLR4/NF- $\kappa B$ signaling pathway might effectively inhibit the UA-induced renal interstitial fibrosis that is mediated by EMT [52]. As shown in our study, LPS acted as a TRL4 agonist. Additionally, our study showed that LPS promoted PDLF apoptosis by inducing implant periodontitis in canines, but PDTC inhibited PDLF apoptosis and alleviated implant periodontitis in canines.

\section{Conclusion}

The present study showed that TLR4 could be highly expressed in peri-implantitis and could participate in the regulation of PDLF apoptosis and proliferation in close association with the development of peri-implantitis. Our study demonstrated that PDTC suppressed PDLF apoptosis and promoted proliferation by inhibiting the expression of NF- $\kappa B$ in canines with peri-implantitis, indicating that PDTC could facilitate a novel aspect of the treatment of patients with peri-implantitis. However, due to the limitations of funds and time, we did not further investigate the possible effects of LPS and LPS-PDTC on normal cells, which will be examined in future studies.

\section{Acknowledgements}

We extend our sincere gratitude to the reviewers for their kind comments.

\section{Disclosure Statement}

No conflicts of interest declared. 


\section{Cellular Physiology Cell Physiol Biochem 2018;49:610-625 \begin{tabular}{ll|l} 
and Biochemistry Published online: 29 August, 2018 & $\begin{array}{l}\text { (c) } 2018 \text { The Author(s). Published by S. Karger AG, Basel } \\
\text { www.karger.com/cpb }\end{array}$ \\
\hline
\end{tabular}}

He et al.: PDTC Inhibits NF- $\mathrm{kB}$ in Peri-Implantitis

\section{References}

1 Nogueira-Filho G, Iacopino AM, Tenenbaum HC: Prognosis in implant dentistry: a system for classifying the degree of peri-implant mucosal inflammation. J Can Dent Assoc 2011;77:b8.

-2 Peri-implant mucositis and peri-implantitis: A current understanding of their diagnoses and clinical implications. J Periodontol 2013;84:436-443.

-3 Van Dyke TE: The impact of genotypes and immune reactivity on peri-implant inflammation: Identification and therapeutic use of anti-inflammatory drugs and immunomodulators. Eur J Oral Implantol 2012;5:S5160.

-4 Algraffee H, Borumandi F, Cascarini L: Peri-implantitis. Br J Oral Maxillofac Surg 2012;50:689-694.

-5 Mellado-Valero A, Buitrago-Vera P, Sola-Ruiz MF, Ferrer-Garcia JC: Decontamination of dental implant surface in peri-implantitis treatment: a literature review. Med Oral Patol Oral Cir Bucal 2013;18:e869-876.

-6 Htet M, Madi M, Zakaria O, Miyahara T, Xin W, Lin Z, Aoki K, Kasugai S: Decontamination of Anodized Implant Surface With Different Modalities for Peri-Implantitis Treatment: Lasers and Mechanical Debridement With Citric Acid. J Periodontol 2016;87:953-961.

7 Pirih FQ, Hiyari S, Leung HY, Barroso AD, Jorge AC, Perussolo J, Atti E, Lin YL, Tetradis S, Camargo PM: A Murine Model of Lipopolysaccharide-Induced Peri-Implant Mucositis and Peri-Implantitis. J Oral Implantol 2015;41:e158-164.

8 Yang B, Zhou Z, Li X, Niu J: The effect of lysophosphatidic acid on Toll-like receptor 4 expression and the nuclear factor-kappaB signaling pathway in THP-1 cells. Mol Cell Biochem 2016;422:41-49.

-9 Malgorzata-Miller G, Heinbockel L, Brandenburg K, van der Meer JW, Netea MG, Joosten LA: Bartonella quintana lipopolysaccharide (LPS): structure and characteristics of a potent TLR4 antagonist for in-vitro and in-vivo applications. Sci Rep 2016;6:34221.

10 Leotoing L, Chereau F, Baron S, Hube F, Valencia HJ, Bordereaux D, Demmers JA, Strouboulis J, Baud V: A20-binding inhibitor of nuclear factor-kappaB (NF-kappaB)-2 (ABIN-2) is an activator of inhibitor of NF-kappaB (IkappaB) kinase alpha (IKKalpha)-mediated NF-kappaB transcriptional activity. J Biol Chem 2011;286:32277-32288.

-11 Kogut MH, He H, Kaiser P: Lipopolysaccharide binding protein/CD14/ TLR4-dependent recognition of salmonella LPS induces the functional activation of chicken heterophils and up-regulation of proinflammatory cytokine and chemokine gene expression in these cells. Anim Biotechnol 2005;16:165-181.

12 Rodrigues A, Queiroz DB, Honda L, Silva EJ, Hall SH, Avellar MC: Activation of toll-like receptor 4 (TLR4) by in vivo and in vitro exposure of rat epididymis to lipopolysaccharide from Escherichia Coli. Biol Reprod 2008;79:1135-1147.

13 Lv R, Xu X, Luo Z, Shen N, Wang F, Zhao Y: Pyrrolidine dithiocarbamate (PDTC) inhibits the overexpression of MCP-1 and attenuates microglial activation in the hippocampus of a pilocarpine-induced status epilepticus rat model. Exp Ther Med 2014;7:39-45.

14 Kwak HJ, Song JS, Heo JY, Yang SD, Nam JY, Cho YS, Cheon HG: Protective effects of pyrrolidine dithiocarbamate against airway inflammation in the ovalbumin-induced mouse model. Eur J Pharmacol 2008;590:355-362.

15 Ivan AL, Campanini MZ, Martinez RM, Ferreira VS, Steffen VS, Vicentini FT, Vilela FM, Martins FS, Zarpelon AC, Cunha TM, Fonseca MJ, Baracat MM, Georgetti SR, Verri WA, Jr., Casagrande R: Pyrrolidine dithiocarbamate inhibits UVB-induced skin inflammation and oxidative stress in hairless mice and exhibits antioxidant activity in vitro. J Photochem Photobiol B 2014;138:124-133.

-16 Kan MH, Yang T, Fu HQ Fan L, Wu Y, Terrando N, Wang TL: Pyrrolidine Dithiocarbamate Prevents Neuroinflammation and Cognitive Dysfunction after Endotoxemia in Rats. Front Aging Neurosci 2016;8:175.

17 Lin X, Liu T, Wu G, Zheng Y, Wismeijer D, Liu Y: Peri-implantitis Induced by Stainless Steel Ligature in Beagle Dogs. Int J Periodontics Restorative Dent 2017;37:e170-e179.

18 Kato A, Miyaji H, Ishizuka R, Tokunaga K, Inoue K, Kosen Y, Yokoyama H, Sugaya T, Tanaka S, Sakagami R, Kawanami M: Combination of Root Surface Modification with BMP-2 and Collagen Hydrogel Scaffold Implantation for Periodontal Healing in Beagle Dogs. Open Dent J 2015;9:52-59.

19 Huang S, Lu F, Zhang Z, Yang X, Chen Y: The role of psychologic stress-induced hypoxia-inducible factor1alpha in rat experimental periodontitis. J Periodontol 2011;82:934-941. 


\section{Cellular Physiology Cell Physiol Biochem 2018;49:610-625 \begin{tabular}{l|l|l} 
DOI: 10.1159/000492997 & $\begin{array}{l}\text { O 2018 The Author(s). Published by S. Karger AG, Basel } \\
\text { www.karger.com/cpb }\end{array}$
\end{tabular}}

He et al.: PDTC Inhibits NF-KB in Peri-Implantitis

20 Hormdee D, Nagasawa T, Kiji M, Yashiro R, Kobayashi H, Koshy G, Noguchi K, Nitta H, Ishikawa I: Protein kinase-A-dependent osteoprotegerin production on interleukin-1 stimulation in human gingival fibroblasts is distinct from periodontal ligament fibroblasts. Clin Exp Immunol 2005;142:490-497.

-21 Liu Q, Stewart J, Wang H, Rashid A, Zhao J, Katz MH, Lee JE, Fleming JB, Maitra A, Wolff RA, Varadhachary GR, Krishnan S, Wang H: Reduced expression of argininosuccinate synthetase 1 has a negative prognostic impact in patients with pancreatic ductal adenocarcinoma. PLoS One 2017;12:e0171985.

22 Livak KJ, Schmittgen TD: Analysis of relative gene expression data using real-time quantitative PCR and the 2(-Delta Delta C(T)) Method. Methods 2001;25:402-408.

-23 Friedrichs K, Gluba S, Eidtmann H, Jonat W: Overexpression of p53 and prognosis in breast cancer. Cancer 1993;72:3641-3647.

24 Heitz-Mayfield LJ, Mombelli A: The therapy of peri-implantitis: a systematic review. Int J Oral Maxillofac Implants 2014;29:S325-345.

-25 Cuzzocrea S, Chatterjee PK, Mazzon E, Dugo L, Serraino I, Britti D, Mazzullo G, Caputi AP, Thiemermann C: Pyrrolidine dithiocarbamate attenuates the development of acute and chronic inflammation. Br J Pharmacol 2002;135:496-510.

-26 Bormann KH, Stuhmer C, Z'Graggen M, Kokemoller H, Rucker M, Gellrich NC: IL-1 polymorphism and periimplantitis. A literature review. Schweiz Monatsschr Zahnmed 2010;120:510-520.

27 Petkovic AB, Matic SM, Stamatovic NV, Vojvodic DV, Todorovic TM, Lazic ZR, Kozomara RJ: Proinflammatory cytokines (IL-1beta and TNF-alpha) and chemokines (IL-8 and MIP-1alpha) as markers of peri-implant tissue condition. Int J Oral Maxillofac Surg 2010;39:478-485.

28 Severino VO, Napimoga MH, de Lima Pereira SA: Expression of IL-6, IL-10, IL-17 and IL-8 in the periimplant crevicular fluid of patients with peri-implantitis. Arch Oral Biol 2011;56:823-828.

-29 Solanki P, Aminoshariae A, Jin G, Montagnese TA, Mickel A: The effect of docosahexaenoic acid (DHA) on expression of IL-1ss, IL-6, IL-8, and TNF-alpha in normal and lipopolysaccharide (LPS)-stimulated macrophages. Quintessence Int 2013;44:393.

-30 Kabanov DS, Serov DA, Zubova SV, Grachev SV, Prokhorenko IR: Dynamics of Antagonistic Potency of Rhodobacter capsulatus PG Lipopolysaccharide against Endotoxin-Induced Effects. Biochemistry (Mosc) 2016;81:275-283.

-31 Xu H, He Y, Yang X, Liang L, Zhan Z, Ye Y, Yang X, Lian F, Sun L: Anti-malarial agent artesunate inhibits TNFalpha-induced production of proinflammatory cytokines via inhibition of NF-kappaB and PI3 kinase/ Akt signal pathway in human rheumatoid arthritis fibroblast-like synoviocytes. Rheumatology (Oxford) 2007;46:920-926.

-32 Li S, Zhong S, Zeng K, Luo Y, Zhang F, Sun X, Chen L: Blockade of NF-kappaB by pyrrolidine dithiocarbamate attenuates myocardial inflammatory response and ventricular dysfunction following coronary microembolization induced by homologous microthrombi in rats. Basic Res Cardiol 2010;105:139-150.

-33 Tang YL, Jiang JH, Wang S, Liu Z, Tang XQ, Peng J, Yang YZ, Gu HF: TLR4/NF-kappaB signaling contributes to chronic unpredictable mild stress-induced atherosclerosis in ApoE-/- mice. PLoS One 2015;10:e0123685.

-34 Hankins JL, Fox TE, Barth BM, Unrath KA, Kester M: Exogenous ceramide-1-phosphate reduces lipopolysaccharide (LPS)-mediated cytokine expression. J Biol Chem 2011;286:44357-44366.

-35 Potnis PA, Dutta DK, Wood SC: Toll-like receptor 4 signaling pathway mediates proinflammatory immune response to cobalt-alloy particles. Cell Immunol 2013;282:53-65.

-36 Rakic M, Nikolic-Jakoba N, Struillout X, Petkovic-Curcin A, Stamatovic N, Matic S, Jankovic S, Aleksic Z, Vasilic D, Lekovic V, Vojvodic D: Receptor activator of nuclear factor kappa B (RANK) as a determinant of peri-implantitis. Vojnosanit Pregl 2013;70:346-351.

-37 Capiralla H, Vingtdeux V, Zhao H, Sankowski R, Al-Abed Y, Davies P, Marambaud P: Resveratrol mitigates lipopolysaccharide- and Abeta-mediated microglial inflammation by inhibiting the TLR4/NF-kappaB/STAT signaling cascade. J Neurochem 2012;120:461-472.

-38 Fu RH, Hran HJ, Chu CL, Huang CM, Liu SP, Wang YC, Lin YH, Shyu WC, Lin SZ: Lipopolysaccharidestimulated activation of murine DC2.4 cells is attenuated by n-butylidenephthalide through suppression of the NF-kappaB pathway. Biotechnol Lett 2011;33:903-910.

-39 Yang T, Olsen KW: Thermal stability and cross-linking of Hb New York [beta 113(G15)Val----Glu]. Hemoglobin 1989;13:147-156. 


\section{Cellular Physiology Cell Physiol Biochem 2018;49:610-625 \begin{tabular}{l|l} 
DOI: 10.1159/000492997 & $\begin{array}{l}\text { O 2018 The Author(s). Published by S. Karger AG, Basel } \\
\text { www.karger.com/cpb }\end{array}$
\end{tabular}}

He et al.: PDTC Inhibits NF-kB in Peri-Implantitis

40 Chung ES, Chung YC, Bok E, Baik HH, Park ES, Park JY, Yoon SH, Jin BK: Fluoxetine prevents LPS-induced degeneration of nigral dopaminergic neurons by inhibiting microglia-mediated oxidative stress. Brain Res 2010;1363:143-150.

41 Cookson BT, Brennan MA: Pro-inflammatory programmed cell death. Trends Microbiol 2001;9:113-114.

$\checkmark 42$ Shi J, Gao W, Shao F: Pyroptosis: Gasdermin-Mediated Programmed Necrotic Cell Death. Trends Biochem Sci 2017;42:245-254.

43 Zhai JX, Zhang ZX, Feng YJ, Ding SS, Wang XH, Zou LW, Ye DQ: PDTC attenuate LPS-induced kidney injury in systemic lupus erythematosus-prone MRL/lpr mice. Mol Biol Rep 2012;39:6763-6771.

-44 Ozcan L, Otunctemur A, Polat EC, Ozbek E, Kirecci SL, Somay A: Selective Nuclear Factor Kappa b (NFkB) Inhibitor, Pyrrolidium Dithiocarbamate Prevents, Long-Term Histologic Damage in Ischemia-Reperfusion Injuries after Delayed Testicular Torsion. Urol J 2016;13:2702-2706.

45 Aziz M, Jacob A, Wang P: Revisiting caspases in sepsis. Cell Death Dis 2014;5:e1526.

46 Shi J, Zhao Y, Wang Y, Gao W, Ding J, Li P, Hu L, Shao F: Inflammatory caspases are innate immune receptors for intracellular LPS. Nature 2014;514:187-192.

-47 Yang C, Zhang H, Huang W, Lin Q, Wei H: [Effect of combined use of PDTC and paclitaxel on proliferation and invasion of human breast cancer cell line MCF-7]. Sheng Wu Yi Xue Gong Cheng Xue Za Zhi 2010;27:1105-1109.

48 Ye K, Wu Y, Sun Y, Lin J, Xu J: TLR4 siRNA inhibits proliferation and invasion in colorectal cancer cells by downregulating ACAT1 expression. Life Sci 2016;155:133-139.

49 Lee SJ, Bae S, Seomun Y, Son MJ, Joo CK: The role of nuclear factor kappa B in lens epithelial cell proliferation using a capsular bag model. Ophthalmic Res 2008;40:273-278.

50 Zhao M, Zhou A, Xu L, Zhang X: The role of TLR4-mediated PTEN/PI3K/AKT/NF-kappaB signaling pathway in neuroinflammation in hippocampal neurons. Neuroscience 2014;269:93-101.

-51 Zhou H, Sheng L, Wang H, Xie H, Mu Y, Wang T, Yan J: Anti-beta2GPI/beta2GPI stimulates activation of THP1 cells through TLR4/MD-2/MyD88 and NF-kappaB signaling pathways. Thromb Res 2013;132:742-749.

52 Liu H, Xiong J, He T, Xiao T, Li Y, Yu Y, Huang Y, Xu X, Huang Y, Zhang J, Zhang B, Zhao J: High Uric AcidInduced Epithelial-Mesenchymal Transition of Renal Tubular Epithelial Cells via the TLR4/NF-kB Signaling Pathway. Am J Nephrol 2017;46:333-342. 